\title{
Global context of disparities in earnings management among enterprises: Evidence from Slovakia
}

\author{
Katarina Valaskova ${ }^{1, *}$, Pavol Durana ${ }^{1}$ \\ ${ }^{1}$ University of Zilina, Faculty of Operation and Economics of Transport and Communications, \\ Univerzitna 1, 01026 Zilina, Slovakia
}

\begin{abstract}
Earnings management is the use of accounting techniques to produce financial reports that present an overly positive view of corporate business activities and financial position. In the context of globalization and internationalisation, the phenomenon of earnings management and legal earnings shifting is an increasingly important issue, particularly in the field of taxation and financial accounting. Earnings management helps to achieve specific targets involving the manipulation of accruals through the discretionary choices of accrual accounting, Thus, the emphasis is given to accrual earnings management, which does not influence the corporate underlying economics but involves the change in the accounting presentation of these economics. The paper depicts the basic concepts of earnings management, reviews the mainstream studies and portrays the genesis of earnings models development. The main aim of the paper is to assess the ability of selected earnings models applied in the national environment of Slovakia, where the issue of earnings manipulation is still unexplored, to detect the problems with earnings manipulation considering individual industry sectors of the national economy. The comparative analysis of the results achieved helps portray the disparities in earnings management among Slovak business entities.
\end{abstract}

\section{Introduction}

Earnings management occurs when managers use judgment in financial reporting and in structuring transactions to alter financial reports to either mislead some stakeholders about the underlying economic performance of the company or to influence contractual outcomes that deepen on reported accounting numbers [1, p. 368]. However, Ronen and Yaari [2, p. 27] provide a comprehensive definition for earnings management that distinguishes between two main activities to manipulate earnings (real versus accrual earnings management); earnings management is a collection of managerial decisions that result in not reporting the true short-term, value-maximizing earnings as known to management. Earnings management can be beneficial (as it signals long-term value), pernicious (as it conceals short-term or long-term value) and neutral (it reveals the short-term true

\footnotetext{
* Corresponding author: katarina.valaskova@fpedas.uniza.sk
} 
performance). The managed earnings result from taking production or investment actions before earnings are realized or making accounting choices that affect the earnings numbers and their interpretation after the true earnings are realized [3].

The accounting field and the research on accounting have been marked by a few milestones, which have had a significant effect on the knowledge and understanding of earnings management. On the theoretical front, the game theory was introduced in the accounting system, described in the studies of Lambert [4], Dye [5], Sankar [6], Arya, Glover and Sunder [7]. As stated by Ronen and Yaari [2], researchers need to understand what to expect of normal accruals to identify managed accruals. The empirical research on earnings management has been marked by a few events that have had a great impact on our knowledge of earnings management [8-15]. Some other studies focus mainly on the theoretical aspect of earnings management, studies such as Healey and Wahlen [1], Dechow and Skinner [16] or Rath and Sun [17]. Latest researches cover the impact of investors' expectations on earnings management [18-20] and policy uncertainty [21-23], the role of multinational corporations $[24,25]$ and changes in earnings quality $[26,27]$. As a result, the concept of earning management is still topical and of interest in financial and accounting literature and this subject assures the importance of this topic among researchers.

The main aim of the paper is to assess the ability of selected earnings models applied in the national environment of Slovakia, where the issue of earnings manipulation is still unexplored, to detect the problems with earnings manipulation considering individual industry sectors of the national economy. In the paper, we mostly focus on the identification of the discretionary accruals based on the relation between total accruals and hypothesized explanatory factors. We use the models, which are based on the determination of total accruals (TA) and changes in total accruals. The purpose of the paper is to apply several models used to detect the earnings manipulation, based on the linear regression analysis. Among different models, we confirmed in the empirical research, that the Jones modified model might offer reliable results in estimating the non-discretionary accrual (NDA) for Slovak enterprises; the results indicate that companies do manipulate earnings, however, the direction of manipulation is different across the economic areas.

The paper is divided into three main sections. The Methodology specifies the methodological steps of empirical research. The Results section describes the findings and depicts the model which is the most relevant to be used in conditions of the Slovak business environment and portrays the differences in earnings management among the individual industrial and economic areas considering the manipulation with earnings, direction and magnitude. The motives of the manipulation are summarized in the Discussion.

\section{Methodology}

The existing earnings management models are applied in the conditions of the Slovak enterprises. We used the Amadeus database supplied by Bureau van Dijk to get the information about the companies in the period of 2014 to 2017. To get relevant results, we determine the limit criteria for the basic accounting variables: the value of total assets is minimum 3,000,000 EUR; the value of total sales minimum 2,000,000 EUR and the value of net income (profit or loss for a period) is at least 100,000 EUR. We got the final sample of 1300 enterprises, however, some of the companies have incomplete or non-available financial data and we also considered the outlying values; thus the final sample consists of 1240 Slovak enterprises.

Ten globally recognized models measuring the earnings management (Table 1), based on the calculation of total accrual (TA), are used to analyse the manipulation with earnings. 
The total accrual is calculated as follows:

$$
T A_{i t}=\triangle R E C_{i t}+\triangle I N V_{i t}-\triangle P A Y_{i t}-D E P_{i t}
$$

where $\quad \triangle R E C_{i t} \quad$ annual change in receivables accounts

$\triangle I N V_{i t} \quad$ annual change in inventories

$\triangle P A Y_{i t} \quad$ annual change in payable accounts

$D E P_{i t} \quad$ depreciation

Almost all models are scaled by $A_{i t-1}$ (total lagged assets), which is used as a deflator to avoid problems with heteroscedasticity.

Table 1. Description of analysed models measuring earnings management.

\begin{tabular}{|c|c|}
\hline Models & Equations \\
\hline Jones & $\frac{N D A_{i t}}{A_{i t-1}}=\frac{T A_{i t}}{A_{i t-1}}=\alpha_{0} \frac{1}{A_{i t-1}}+\alpha_{1} \frac{\Delta R E V_{i t}}{A_{i t-1}}+\alpha_{2} \frac{P P E_{i t}}{A_{i t-1}}+\varepsilon_{i t}$ \\
\hline Mod. Jones & $\frac{N D A_{i t}}{A_{i t-1}}=\frac{T A_{i t}}{A_{i t-1}}=\alpha_{0} \frac{1}{A_{i t-1}}+\alpha_{1} \frac{\Delta R E V_{i t}-\triangle R E C_{i t}}{A_{i t-1}}+\alpha_{2} \frac{P P E_{i t}}{A_{i t-1}}+\varepsilon_{i t}$ \\
\hline $\begin{array}{l}\text { Industry } \\
\text { based }\end{array}$ & $N D A_{t}=\gamma_{1}+\gamma_{2} \cdot$ median $\left(T A_{t}\right)$ \\
\hline $\begin{array}{l}\text { Jeter \& } \\
\text { Shivakumar }\end{array}$ & $\frac{T A_{i t}}{A_{i t-1}}=\alpha_{0} \frac{1}{A_{i t-1}}+\alpha_{1} \frac{\Delta R E V_{i t}}{A_{i t-1}}+\alpha_{2} \frac{P P E_{i t}}{A_{i t-1}}+\alpha_{3} \frac{C F O_{i t}}{A_{i t-1}}+\varepsilon_{i t}$ \\
\hline Kasznik & $\frac{N D A_{i t}}{A_{i t-1}}=\frac{T A_{i t}}{A_{i t-1}}=\alpha_{0} \frac{1}{A_{i t-1}}+\alpha_{1} \frac{\Delta R E V_{i t}}{A_{i t-1}}+\alpha_{2} \frac{P P E_{i t}}{A_{i t-1}}+\alpha_{3} \frac{\Delta C F O_{i t}}{A_{i t-1}}+\varepsilon_{i t}$ \\
\hline Key & $\frac{N D A_{i t}}{A_{i t-1}}=\frac{T A_{i t}}{A_{i t-1}}=\alpha_{0} \frac{1}{A_{i t-1}}+\alpha_{1} \frac{\Delta R E V_{i t}}{A_{i t-1}}+\alpha_{2} \frac{P P E_{i t}}{A_{i t-1}}+\alpha_{3} \frac{I A_{i t}}{A_{i t-1}}+\varepsilon_{i t}$ \\
\hline $\begin{array}{l}\text { Teoh, Welch } \\
\text { \& Wong }\end{array}$ & $\frac{N D A_{i t}}{A_{i t-1}}=\frac{T A_{i t}}{A_{i t-1}}=\alpha_{0} \frac{1}{A_{i t-1}}+\alpha_{1} \frac{\Delta S A L E_{i t}-\Delta R E C_{i t}}{A_{i t-1}}+\varepsilon_{i t}$ \\
\hline Kothari & $\frac{N D A_{i t}}{A_{i t-1}}=\frac{T A_{i t}}{A_{i t-1}}=\alpha_{0} \frac{1}{A_{i t-1}}+\alpha_{1} \frac{\Delta R E V_{i t}-\Delta R E C_{i t}}{A_{i t-1}}+\alpha_{2} \frac{P P E_{i t}}{A_{i t-1}}+\alpha_{3} \frac{R O A_{i t-1}}{A_{i t-1}}+\varepsilon_{i t}$ \\
\hline McNichols & $\Delta W C_{t}=b_{0}+b_{1} C F O_{t-1}+b_{2} C F O_{t}+b_{3} . C F O_{t+1}+b_{4} \Delta$ sales $+b_{5} . P P E+\varepsilon_{i, t}$ \\
\hline $\begin{array}{l}\text { Dechow \& } \\
\text { Dichev }\end{array}$ & $\Delta W C_{i, t}=\beta_{0}+\beta_{1} C F O_{i, t-1}+\beta_{2} C F O_{i, t}+\beta_{3} C F O_{i, t+1}+\varepsilon_{i, t}$ \\
\hline \multirow[t]{14}{*}{ variables } & total accrual in the year $\mathrm{t}$ \\
\hline & total assets in the year $\mathrm{t}-1$ \\
\hline & $\Delta R E V_{i t} \quad$ annual change in the value of revenues in the year $\mathrm{t}$ \\
\hline & $\Delta R E C_{i t}$ annual change in the value of receivables in the year $\mathrm{t}$ \\
\hline & $P P E_{i t} \quad$ long-term tangible assets in the year $\mathrm{t}$ \\
\hline & $\mathrm{CFO}_{\text {it }} \quad$ operating cash flow in the year $\mathrm{t}$ \\
\hline & $C F O_{\text {it }-1}$ operating cash flow in the year $\mathrm{t}-1$ \\
\hline & $C F O_{\text {it }+1}$ operating cash flow in the year $\mathrm{t}+1$ \\
\hline & median $\left(T A_{t}\right)$ median value of total accruals in a specific industry \\
\hline & long-term intangible assets in the year $\mathrm{t}$ \\
\hline & $\triangle S A L E_{i t}$ annual change in the value of revenues in the year $\mathrm{t}$ \\
\hline & $R O A_{i t-1}$ return on assets in the year $\mathrm{t}-1$ \\
\hline & $\Delta W C t \quad$ annual change in the value of working capital in the year $\mathrm{t}$ \\
\hline & prediction error \\
\hline
\end{tabular}

Choosing the best model to detect earnings management in the country is followed by the estimation of discretionary accruals, using the coefficients of the calculated regression equation, for every enterprise in the dataset and each year. Then we can claim if the 
enterprises manipulate earnings or not and identify the trend (upward or downward manipulation). The classification of the total dataset according to the NACE allows analysing the sign, magnitude and dimension of manipulation with earnings in individual economic sectors.

\section{Results}

To determine which model is the most appropriate to detect the earnings management in each country, we have to judge the assessing criteria- adjusted R squared, predicted sign of variables, standard deviation of the variables and significance level of the model and its variables. The adjusted R-squared compares the descriptive power of regression models, thus, we may compare the results over time and tendencies among models. The higher the value of adjusted R squared, the better the explaining ability of the model. The predicted sign of variables compares the expectations of the development of the variables with their real values. The match in signs indicates better explanation ability of the model variable and thus more accurate detection of earnings management. Standards deviation is a measure that is used to quantify the amount of dispersion of a set of data value and assesses the effectiveness of the model. Low values of standard deviation demonstrate that the data are very close to the mean value and thus the model is better to explain the issue of earnings manipulation. Considering the significance level of the model and its variables, the truthfulness of results is evaluated. If the model itself or its variables are not statistically significant at the given significance level (we consider 5\%), then this model (variable) does not explain the manipulation with earnings sufficiently.

Table 2 depicts the fulfilment of the assessing criteria for each earnings management model. The model, which meets the requirements in each criterion, is considered the most appropriate. The analysis reveals that the Jones modified model offers the most reliable results in estimating the non-discretionary accrual (NDA) for Slovak enterprises.

Table 2. Assessment of earnings management models.

\begin{tabular}{|c|c|c|c|c|c|c|}
\hline \multirow{2}{*}{ EM model } & \multicolumn{5}{|c|}{ Assessing criteria } & \\
\cline { 2 - 6 } & adjusted & predicted & standard & \multicolumn{2}{c|}{ significance } & n. of met \\
R square & sign & deviation & model & variable & criteria \\
\hline Jones & $\mathbf{x}$ & $\checkmark$ & $\checkmark$ & $\checkmark$ & $\checkmark$ & 4 \\
\hline Jones modified & $\checkmark$ & $\checkmark$ & $\checkmark$ & $\checkmark$ & $\checkmark$ & 5 \\
\hline Industrial-based & $\mathbf{x}$ & $\mathbf{x}$ & $\checkmark$ & $\checkmark$ & $\checkmark$ & 3 \\
\hline Jeter \& Shivakumar & $\mathbf{x}$ & $\mathbf{x}$ & $\mathbf{x}$ & $\checkmark$ & $\mathbf{x}$ & 1 \\
\hline Kasznik & $\mathbf{x}$ & $\mathbf{x}$ & $\mathbf{x}$ & $\checkmark$ & $\checkmark$ & 2 \\
\hline Key & $\checkmark$ & $\checkmark$ & $\mathbf{x}$ & $\checkmark$ & $\checkmark$ & 4 \\
\hline Teoh, Welch \& Wong & $\mathbf{x}$ & $\mathbf{x}$ & $\checkmark$ & $\mathbf{x}$ & $\mathbf{x}$ & 1 \\
\hline Kothari & $\checkmark$ & $\checkmark$ & $\mathbf{x}$ & $\checkmark$ & $\mathbf{x}$ & 3 \\
\hline McNichols & $\mathbf{x}$ & $\mathbf{x}$ & $\mathbf{x}$ & $\checkmark$ & $\mathbf{x}$ & 1 \\
\hline Dechow \& Dichev & $\mathbf{x}$ & $\mathbf{x}$ & $\mathbf{x}$ & $\mathbf{x}$ & $\mathbf{x}$ & 0 \\
\hline
\end{tabular}

The Jones modified model was used to calculate discretionary accruals (DA) for each company using the values of the coefficients of variables from the regression analysis. To reveal the manipulation with earnings, we generate the hypothetical sample of companies that do not manage earnings (discretionary accruals are close to zero). Comparing the results of the calculated discretionary accrual (which is either positive or negative but not zero) clarifies the existence of differences indicating that the Slovak companies manipulate earnings. The direction of manipulation, the magnitude of earnings management and its dimension are portrayed in Table 3 . 
Table 3. Direction, magnitude and dimension of earnings manipulation.

\begin{tabular}{|c|c|c|c|c|}
\hline Year & 2017 & 2016 & 2015 & \\
\hline Enterprises with + DA & 681 & 770 & 741 & \\
\hline Enterprises with; - DA & 559 & 470 & 499 & \\
\hline Mean DA & -0.00274 & 0.01653 & 0.01606 & \\
\hline Standard deviation DA & 0.15808 & 0.19555 & 0.17268 & \\
\hline Median DA & 0.01060 & 0.02760 & 0.02504 & \\
\hline & & & & Average \\
\hline$\%$ of enterprises with + DA & $54.92 \%$ & $62.10 \%$ & $59.76 \%$ & $58.92 \%$ \\
\hline$\%$ of enterprises with - DA & $45.08 \%$ & $37.90 \%$ & $40.24 \%$ & $41.08 \%$ \\
\hline Mean value of - DA & 0.1091 & 0.1140 & 0.1209 & 0.1147 \\
\hline Mean value of + DA & 0.0846 & 0.0962 & 0.1083 & 0.0963 \\
\hline $\begin{array}{l}\text { Difference of mean }+ \text { and - } \\
\text { DA }\end{array}$ & -0.0245 & -0.0178 & -0.0126 & -0.0183 \\
\hline Dimension of + DA & 0.0464 & 0.0597 & 0.0647 & 0.0570 \\
\hline Dimension of - DA & 0.0492 & 0.0432 & 0.0486 & 0.0470 \\
\hline
\end{tabular}

The mean value of discretionary accruals in individual years changes slightly. The positive values were achieved in 2016 and 2015 indicating that companies manage earnings upwards, in 2017 the downward manipulation was detected as the mean value is negative. Relative high values of the standard deviation of discretionary accruals present high dispersion of accruals and relevant differences among enterprises within the country. In all years, the percentage of positive discretionary accrual exceeds the percentage of negative discretionary accruals- the enterprises in both countries manage earnings upwards. The magnitude of earnings management is calculating using the means of absolute values of positive and negative discretionary accruals. The absolute values of the negative discretionary accruals (average value of 0.1147 ) are higher than the absolute values of positive discretionary accruals $(0.0963)$ which means that the downward manipulation is more significant than the upward manipulation. The results reveal that Slovak enterprises tend to manipulate earnings upward, however, the downward manipulation is much more extensive. The dimension of the earnings manipulation is calculated as a multiplication of the absolute values of means of positive (negative) discretionary accruals by the percentage of the cases with positive (negative) discretionary accruals. Comparing the average values, the positive discretionary accrual (0.057) exceeds the negative one (0.047) showing that the dimension of manipulation by increasing earnings is more considerable than the manipulation by decreasing earnings. However, the purpose of the paper is to detect the problems with earnings manipulation considering individual industry and economy sectors of the national economy (using NACE classification*).

Table 4 portrays the three-years-average value of monitored discretionary accruals measures.

\footnotetext{
* A - Agriculture, forestry and fisheries; B - Mining and quarrying; C - Industrial Production; D Supply of electricity, gas, steam and cold air; E - Water supply, sewerage, waste management and remediation activities; F - Construction; $G$ - Wholesale and retail; repair of motor vehicles and motorcycles; H - Transportation and storage; I - Accommodation and catering services; J Information and communication; K - Financial and insurance activities; L - Real estate activities; M Professional, scientific and technical activities; N - Administrative and supporting activities; Q Health and social work;, R - Arts, entertainment and recreation;, S - Other service activities
} 
Table 4. Detection of earnings management according to NACE classification.

\begin{tabular}{|c|c|c|c|c|c|c|c|c|}
\hline NACEcode & No. & $\begin{array}{c}\text { \% } \\
\text { +DA }\end{array}$ & $\begin{array}{c}\text { \% } \\
\text {-DA }\end{array}$ & $\begin{array}{c}\text { Mean } \\
\text {-DA }\end{array}$ & $\begin{array}{c}\text { Mean } \\
\text { +DA }\end{array}$ & $\begin{array}{c}\text { Mean } \\
\text { diff. }\end{array}$ & $\begin{array}{c}\text { Dim. } \\
\text { +DA }\end{array}$ & $\begin{array}{c}\text { Dim. } \\
\text {-DA }\end{array}$ \\
\hline A & 46 & 57.25 & 42.75 & 0.0848 & 0.0743 & -0.0105 & 0.0426 & 0.0357 \\
\hline $\mathbf{B}$ & 10 & 70.37 & 33.33 & 0.0766 & 0.0889 & 0.0124 & 0.0575 & 0.0262 \\
\hline $\mathbf{C}$ & 426 & 59.78 & 40.22 & 0.1087 & 0.088 & -0.0199 & 0.0529 & 0.0430 \\
\hline $\mathbf{D}$ & 43 & 52.71 & 34.88 & 0.1334 & 0.0886 & -0.0448 & 0.0453 & 0.0481 \\
\hline $\mathbf{E}$ & 13 & 51.28 & 48.72 & 0.0640 & 0.1094 & 0.0454 & 0.0569 & 0.0313 \\
\hline $\mathbf{F}$ & 53 & 54.09 & 45.91 & 0.1405 & 0.1447 & 0.0042 & 0.0796 & 0.0616 \\
\hline $\mathbf{G}$ & 340 & 62.94 & 37.06 & 0.1048 & 0.0884 & -0.0163 & 0.0559 & 0.0385 \\
\hline $\mathbf{H}$ & 68 & 44.61 & 55.93 & 0.0942 & 0.0809 & -0.0133 & 0.0378 & 0.0521 \\
\hline $\mathbf{I}$ & 8 & 70.83 & 29.17 & 0.0728 & 0.1254 & 0.0526 & 0.0858 & 0.0227 \\
\hline $\mathbf{J}$ & 44 & 43.93 & 56.06 & 0.1425 & 0.1237 & -0.0188 & 0.0544 & 0.0804 \\
\hline $\mathbf{K}$ & 16 & 41.67 & 58.33 & 0.1015 & 0.1170 & 0.0154 & 0.0538 & 0.0632 \\
\hline $\mathbf{L}$ & 34 & 78.43 & 21.57 & 0.2002 & 0.1464 & -0.0538 & 0.1141 & 0.0535 \\
\hline $\mathbf{M}$ & 50 & 54.67 & 45.33 & 0.1243 & 0.1065 & -0.0178 & 0.0589 & 0.0566 \\
\hline $\mathbf{N}$ & 38 & 46.94 & 53.51 & 0.1507 & 0.1599 & 0.0092 & 0.0741 & 0.0806 \\
\hline $\mathbf{Q}$ & 29 & 67.82 & 32.18 & 0.1879 & 0.0869 & -0.1010 & 0.0599 & 0.0596 \\
\hline $\mathbf{R}$ & 21 & 52.38 & 47.62 & 0.1494 & 0.1160 & -0.0334 & 0.0625 & 0.0742 \\
\hline $\mathbf{S}$ & 1 & 33.33 & 66.67 & 0.0186 & 0.0406 & 0.0011 & 0.0135 & 0.0124 \\
\hline
\end{tabular}

The manipulation with earnings has slightly different results when considering individual categories of NACE classification. In almost sectors of the economy, the percentage of positive discretionary accrual exceeds the percentage of negative discretionary accrual indicating that the upward manipulation is more typical for Slovak Enterprises.

\section{Discussion}

Considering the analysis and calculation of discretionary accruals and a level of earnings manipulation, several groups of enterprises might be formed.

1. Enterprises, which manipulate earnings upwards, having the absolute values of the negative discretionary accruals higher than the absolute values of the positive discretionary accruals (measuring the magnitude - downward manipulation is more considerable than the upward one); the dimension of manipulation by increasing earnings is more significant. This technique of earnings management is typical of companies operating in Agriculture, forestry and fisheries; industrial production; wholesale and retail; real estate activities; professional, scientific and technical activities, health and social work and in the sector of arts, entertainment and recreation (NACE codes A, C, G, L, M, Q, R).

2. Enterprises, which manipulate earnings upwards, having the absolute values of the positive discretionary accruals higher than the absolute values of the negative discretionary accruals (measuring the magnitude - upward manipulation is more considerable than the downward one); the dimension of manipulation by increasing earnings is more significant. This manipulation with earnings practice enterprises in the sector of mining and quarrying; water supply, sewerage and waste management; construction and accommodation and catering services (NACE codes B, E, F, I).

3. Enterprises, which manipulate earnings upwards, having the absolute values of the negative discretionary accruals higher than the absolute values of the positive discretionary accruals (measuring the magnitude - downward manipulation is more considerable than the upward one); the dimension of manipulation by decreasing earnings is more significant, e.g. 
enterprises operating in the sector of supply of electricity, gas, steam and cold air (NACE code D).

4. Enterprises, which manipulate earnings downwards (Table 4 in grey colour); measuring the magnitude - downward manipulation is more considerable than the upward one (typical for enterprises in transport sector and IT sector), however, upward manipulation is more considerable than the downward one in enterprises operating in the sector of financial and insurance activities and administrative activities; the dimension of manipulation by decreasing earnings is more significant.

The results indicate that the downward manipulation with earnings is typical for enterprises achieving relatively high turnovers (profits), especially the IT sector and financial and insurance activities. The motive for this action might be the taxation as enterprises prefer to decrease their tax expenses. All the enterprises managing earnings downwards (NACE CODES H, J, K, N) are regulated by specific legislation, thus, it drives the enterprises to manage discretionary accruals downwards to demotivate the regulators from issuing strict regulations that might harm the business activities [11]. On the other hand, the upward manipulation with earnings may be a corporate strategy as enterprises aim to avoid reporting low earnings to get better creditworthiness and receive debt at lower costs. However, also the contracting motives (management compensation, the managerial ability of enterprise characteristics) and the external ones play an important role. Considering the role of suppliers and customers, an enterprise that relies on specific suppliers or customers (which is the case of small and medium-sized Slovak companies) is more inclined to manage earnings to influence its performance [2]. To establish a long-term relationship with suppliers and customers and build a reputation, enterprises tend to manage earnings upwards. Thus, managers bring pressure to improve performance relative to their competitors and there are more incentives for earnings management

An important role is played by the industry. Enterprises within the same industry have similar legal and financial incentives and consider the behaviour of their competitors when making decisions. Enterprises operating in the same industry consider the performance of their competitors when managing earnings [28, 29]. Roychowdhury [30] and Sundvik [31] claim that the industry may have an impact on discretionary accruals and earning management phenomenon, which is also confirmed by the study of Toniato et al. [32] which prove the differences in industry characteristics and earnings management behaviour between various economies.

\section{Conclusions}

Earnings management is the active manipulation of accounting results for the purpose of creating an altered impression of business performance. Given that managers can choose accounting policies from a set (e.g. GAAP standards), it is natural to expect that they will choose policies so as to maximize their own utility and the market value of the enterprise, which is the basic principle of earnings management [33].

The analysis of 1,240 Slovak enterprises proves that the Jones modified model is the most relevant to estimate the non-discretionary accruals. The results indicate that enterprises manage earnings mostly upwards, however, the magnitude and dimension of manipulation change over the years. The comparative analysis of the results achieved helps portray the disparities in earnings management among Slovak business entities operating in different economic categories following the NACE classification. The results show, that downward manipulation of earnings is typical of enterprises operating in the sector of transportation and storage, IT sector, financial and insurance activities and administrative and supporting services. The external incentives, e.g. taxation and legislative regulations, 
might be the reason. The majority of Slovak enterprises manage earnings upwards, as a possible reason for managerial reputational and creditworthy motives.

The detection of earnings management is limited only to a one country sample and to a specific time horizon. Thus, the further research should be focused on the detection of earnings management in different countries, e.g. in the Visegrad group countries, to highlight the disparities and similarities of earnings management in countries with a similar economic and political background.

This research was financially supported by the Ministry of Education, Science, Research and Sport of the Slovak Republic and Slovak Academy of Sciences - VEGA 1/0210/19 Research on innovative attributes of qualitative and quantitative fundaments of an opportunistic modelling of earnings.

\section{References}

1. P. Healy, P., J. Wahlen, A review of the Earnings Management literature and its implications for standards setting Accounting Horizon 13, 365-383 (1999)

2. J. Ronen, V. Yaari, Earning Management: Emerging Insights in Theory, Practice and Research (Springer, New York, 2008)

3. P. Kristofik, J. Horak, P. Suler, Provision of trade credits in relation to corporate payment ability: A case study of the Visegrad four. Ekonomicko-manazerske spektrum 13, 96-108 (2019)

4. A. Lambert, Income smoothing as rational equilibrium behaviour. Accounting Review 59, 604-618 (1984)

5. R.A. Dye, Earnings management in an overlapping generation model. Journal of Accounting Research 26, 195-235 (1988)

6. M.R. Sankar, The impact of alternative forms of earnings management on the returnsearnings relation. SSRN, 146732 (1999)

7. A. Arya, J. Glover, S. Sunder, Are unmanaged earnings always better for sharehodlers ? Accounting Horizon 17, 111-116 (2003)

8. P. Healy, The effects of bonus schemes on accounting decisions. Journal of Accounting and Economics 7, 85-107 (1985)

9. K. Schipper, Commentary on earnings management, Accounting Horizons 3, 91-102 (1989)

10. M. McNichols, P. Wilson, Research design issues in earnings management studies. Journal of Accounting Research 26, 1-32 (1985)

11. J. Jones, Earnings Management during Import Relief Investigations. Journal of Accounting Research 29, 193-228 (1991)

12. P. Dechow, R. Sloan, A. Sweeney, Detecting earnings management. Accounting Review 70, 193-225 (1995)

13. P. Dechow, I. Dichev, The quality of accruals and earnings: The role of accrual estimation errors. Accounting Review 77, 35-59 (2002)

14. S. Kothari, A. Leone, C. Wasley, Performance match discretionary accrual measures. Journal of Accounting and Economics 39, 163-197 (2005)

15. J. Ye, Accounting Accruals and Tests of Earnings Management (Baruch College, New York, 2007) 
16. P. Dechow, D.J. Skinner, Earnings management, reconciling the views of accounting academics, practitioners and regulators. Accounting Horizon 14, 235-250 (2000)

17. S. Rath, L. Sun, The development of Earnings Management Research. International Review of Business Research Papers 4, 265-277 (2008)

18. D. Kai, Investor expectations, earnings management, and esset prices. Journal of Economic Dynamics and Control 105, 134-157 (2019)

19. L. Ugur, The role of foreign institutional investors in restraining earnings management activities across countries. Journal of International Business Studies 50, 895-922 (2019)

20. J. Kliestikova, M. Misankova, T. Kliestik, Bankruptcy in Slovakia : International comparison of the creditor's position. Oeconomia Copernicana 8, 221-237 (2017)

21. K. Yung, A. Root, Policy unvertainty and earnings management. Journal of Business Research 100, 255-267 (2019)

22. B. Gavurova, M. Packova, M. Misankova, L. Smrcka, Predicitive potential and risks of selected bankruptcy prediction models in the Slovak business environment. Journal of Business Economics and Management 18, 1156-1173 (2017)

23. N. Shpak, O. Sorochak, M. Hvozd, W. Sroka, Risk evaluation of the reengineering projects : A case study analysis. Scientific Annals of Economics and Business 65, 215226 (2018)

24. C. Bueselinck, S. Cascino, M. Deloof, A. Vanstraelen, Earnings management within multinational corporations. Accounting Review 94, 45-76 (2019)

25. S.J. Huxley, M. Sidaoui, Gaining Market Share in Emerging Markets Portfolios by Moderating Extreme Returns: The Case of Peru. Economics, Management and Financial Markets 13, 37-55 (2018)

26. A. Beyer, I. Guttman, I. Marinovic, Earnings management and earnings quality: Theory and evidence. Accounting Review 94, 77-101 (2019)

27. D. Kantarelis, Screening Stocks based on the Rational Approach to Decision-Making Economics, Management and Financial Markets 13, 32-62 (2018)

28. J. Abakumova, O. Primierova, Globalization, growth and inequality: testing causality and asymmetries. Ekonomicko-manazerske spektrum 12, 83-95 (2018)

29. R. Stoklasová, Econometric nalysis of SMEs in Eurozone. Forum Scientiae Oeconomia 6, 19-29 (2018)

30. S. Roychowdhury, Earnings management through real activities manipulation. Journal of Accounting and Economics 42, 335-370 (2006)

31. D. Sundvik, Industry differences in earnings management- Evidence from Finnish private firms (Hanken School of Economics, Helsinki, 2013)

32. J. Toniato, J.E.F. Almeida, F. Moraes, Earnings management and industry classification in Brazil: An exploratory investigation. Corporate Ownership and Control 3, 144-149 (2006)

33. W. Scott, Financial Accounting theory (Prentice-Hall, New Jersey, 1997) 